\title{
The growth of private higher education in Brazil: implications for equity and quality.
}

\author{
Tristan McCowan \\ Journal of Education Policy (2004), 19 (4), 453 — 472
}

\begin{abstract}
:
There has been a dramatic growth in private higher education in Brazil in recent years. The World Bank has promoted this expansion on the basis of the private providers' ability to ensure a rapid increase in enrolment, to improve quality through competition between institutions and to bring benefits for society at little public cost. However, the charging of fees means that the majority of Brazilians do not have access, and that inequalities are reproduced due to the relation between course costs and the value of the final diploma. Equitable access is, therefore, far from being achieved and is unlikely even with an increase in student loans and government subsidies. The contribution of private universities to the long-term development of society is seen to be limited, due to lack of investment in research and academic staff.
\end{abstract}

\section{Introduction}

Private higher education is not a modern phenomenon. The first universities in Europe were privately run associations, and national higher education systems were only established in the nineteenth and twentieth centuries, either through the founding of new institutions, or the provision of state funding for existing ones. In many countries, particularly the USA, a dual system has existed for many years, with prestigious institutions in the public and private sectors, and state funding for research given to both.

In recent years, however, dramatic changes in higher education (HE) have been seen throughout the world, caused by new models of social and economic policy, and by developments in science and technology. The new policy framework in HE is characterized by two forms of privatization: firstly the growth of private universities, and secondly the increasing proportion of private funding for state universities, through the introduction of 
fees, and funding of research by the private sector ${ }^{1}$. This study will focus on the first of these forms. As a general rule, wealthy countries with well-established systems of HE have been most affected by the second form of privatization, while low and middle-income countries (LMICs) like Brazil, whose systems are far from satisfying demand, have seen some of the same changes in their public systems, but also a rapid growth in the number and size of private institutions. In some cases this has been dramatic: in the course of the 1980s, the number of private higher education institutions (HEIs) in Chile grew from 8 to 180 (Altbach 2002).

These changes in HE are perhaps of little surprise in the context of the neo-liberal reforms implemented throughout the world since the 1980s, and the entry of profit-making companies into many lucrative areas of the public services. However, the question is complex, as the private institutions and the international organizations that support them argue strongly that they are contributing not only to efficiency and economic growth, but also to the equitable development of society. These claims must be taken seriously: after all, the private sector has succeeded in bringing a rapid expansion in tertiary enrolment in LMICs, allowing a greater proportion of society to have access to this level of education.

This paper will analyse the phenomenon in the context of Brazil, a country which well exemplifies this growth in the private sector. While there has been a strong presence of private institutions since the 1940s, there has been a new surge in the last ten years. The number of undergraduates in private HEIs has increased by $84 \%$ since 1998 , and the private sector now counts for $70 \%$ of total enrolment, an industry of around US\$4 billion (INEP 2003b). Before looking at this case, however, there will be a closer examination of the general arguments in favour of private HE, in particular those advocated by the World Bank.

\section{The World Bank and Higher Education}

The influence of the World Bank on the education policy of LMICs should not be underestimated. Since the 1980s, the Bank has increased its emphasis on education, and with the decline of UNESCO, precipitated by the withdrawal of the USA and the UK in $1984^{2}$, has become the largest international source of funds and producer of educational research (Leher 
1999). Most LMICs are heavily dependent on World Bank loans to develop their education systems, and these are almost always tied to the adoption of particular policies.

The World Bank considers there to be a world-wide crisis in HE, with even the industrialized countries struggling to absorb the high costs of research and rising enrolments. While finance is the primary concern, the Bank is also concerned with quality - a higher education that will equip students for the modern economy - and equity - one that can be expanded from its traditional elitist base.

Nevertheless, one of best-known of the Bank's policy recommendations is the diversion of state funding from higher to basic education, principally primary schools. Investment in HE is seen to have lower economic returns, and to contribute less to social equity. The private sector is therefore invited to absorb the increasing demand for higher education in place of the retreating State. This is realized in the two main ways outlined above: firstly the diversification of funding sources of public universities, including 'cost-sharing' with students and service provision to the private sector; secondly, the development of private HE institutions.

There are three main lines of argumentation in favour of the private sector:

1) Private sector involvement will increase the number of places in HE, thus widening access and increasing equity.

2) The traditional model of the European research university is inappropriate for LMICs and for the modern economy. Private universities can provide an education more suited to students' needs, and competition between them will increase quality.

3) Private sector involvement will provide $\mathrm{HE}$ at little public cost.

These ideas are presented in the Bank's 1994 publication, Higher Education: the Lessons of Experience. There is some change of emphasis in the later Education Sector Strategy (1999) and particularly in the joint publication with UNESCO (The Task Force on Higher Education and Society 2000): here the Bank acknowledges that it had underestimated the economic returns of $\mathrm{HE}$ and some of the dangers of private provision, but even so shows little real commitment to promoting public universities, except as a safety net for those unable to afford private ones. 
In Educational Change in Latin America and the Caribbean (1999) the Bank states that:

Constraints on government finance and the need for a broader range of higher education institutions mean that the private sector should be encouraged to play a bigger role in both financing and providing higher education in LAC [Latin America and the Caribbean]. Failure to use government funds to leverage private finance will constrain access and equity of access to higher education. (World Bank 1999b: 62)

In addition, the Bank sees private institutions as well suited for the task of 'diversifying and reforming tertiary education to raise quality and efficiency' (World Bank 1999b:11), including the introduction of short courses, polytechnic courses and distance or virtual education. The Bank's planned 'Higher Education Improvement Project' in Brazil, involving a loan of US\$615 million, is aimed primarily at increasing the efficiency of the system, reducing costs per student and restructuring the student loan programme.

The World Bank is not the sole cause of the expansion of the private sector in LMICs: of the supranational agencies, the Inter-American Development Bank - whose policies are similar to those of the World Bank - is also an important player in Latin America (Rodríguez-Gómez and Alcántara 2001). In many cases the ruling elites of countries like Brazil have welcomed these new policies of privatization, and local and foreign entrepreneurs have been quick to capitalize on the commercial opportunities. The question that must be addressed is whether the expansion of the private sector has brought the results of equity and quality predicted by the World Bank.

\section{Higher Education in Brazil}

Brazil's education system displays the extreme inequality that characterizes the country as a whole. While a child of an upper-middle class family is assured an education comparable to that of any developed country, the poor can expect little more than a few years at an underresourced primary school. Primary enrolment is now almost universal $-97 \%$ according to UNESCO (2001) - but there are high rates of drop out and repetition. Secondary enrolment 
has risen sharply and has now reached $71 \%$, but here as at the primary level there are problems of quality, and severe underfunding for public schools in poor areas. Less than half of those at secondary level have survived through their studies without repeating a year (INEP 2003a). While there are a number of significant initiatives by social movements and local governments aiming to address these inequalities (Gandin and Apple 2002, Gentili and McCowan 2003, McCowan 2003), educational opportunity on the national scale is deeply undemocratic.

Higher education is no exception. Brazil has a small number of first-rate universities, particularly in the state of São Paulo, with relatively high levels of expenditure per student and developed research programmes. However, gross enrolment nationwide is only $17 \%$, compared to $48 \%$ in Argentina and 38\% in Chile (UNESCO 2001), and since many of the students are older than 24 (the gross calculation is based on the 17-24 age group), the net rate of enrolment is as low as 9\% (IBGE 2001). Students are almost exclusively from the upper socio-economic levels ( $71 \%$ of students are from the top quintile of family income), there is low representation of the African Brazilian population, and universities are concentrated mainly in the wealthier South-Eastern and Southern regions ${ }^{3}$.

The administration of Fernando Henrique Cardoso from 1994 to 2002 brought major changes in education policy. Following World Bank recommendations, attention was focused primarily on basic education, with extra funds allocated to the primary level, attempts made to equalize regional differences and decentralization of control to the municipalities. Changes to the universities were inevitable. The relatively high expenditures per student in public universities - around US\$13, 500 per student per year (Salomon 2003) - were unlikely to be sustained by a government who had adopted the belief that the State's responsibility was to regulate and not provide higher education (Gentili 2001). In the last ten years there has been a stagnation of funding for public HE, with a decrease in the number of full-time staff and little investment in infrastructure (Trindade 2003).

There are currently three official categories of higher education institution in Brazil:

1. Universities: institutions required to carry out research and community outreach (extensão) as well as tuition, to have $1 / 3$ of the teaching staff with $\mathrm{MA}$ or $\mathrm{PhD}$, and $1 / 3$ of the teaching staff working full time. They have the highest level of autonomy. 
2. University centres: multi-course institutions not required to carry out research, but with autonomy to open new courses without the permission of the Ministry.

3. Integrated faculties, faculties, and institutes or schools of HE: smaller institutions, with little autonomy, and which must have new courses approved one by one by the Ministry.

(Neves 2002)

Most institutions in the public sector are universities, and their administration is split between the three levels of Brazilian government: federal, state and municipal. The federal government runs 61 universities, including many of the oldest and most prestigious institutions, with centralized control. State governments, which are responsible for most secondary and some primary education, run a further 61 universities, including the Universities of São Paulo and Campinas, widely considered the best in the country. Municipal governments have responsibility primarily for primary schools, but also run 75 smaller HE institutions, mainly providing technical courses.

University entrance is based on an exam known as the vestibular, specific to each institution ${ }^{4}$. Candidates often attend preparatory courses known as pre-vestibulares, either during the final stages of secondary school or after completion. As most of these courses are expensive, possibilities for students from poor families to pass the vestibular are low, since they have normally had inferior pre-university schooling and are therefore in greater need of the preparatory course ${ }^{5}$. Entrance exams for public universities are the most competitive, with nearly ten candidates for every place (in private universities the ratio is less than two to one) (IIESALC 2002). The cruel irony of Brazilian higher education, therefore, is that the majority of the free higher education places are filled by students from wealthy backgrounds who have been able to afford private primary and secondary schooling, and a pre-vestibular course. This, however, does not mean that the private universities cater for the lower socio-economic groups, a commonly accepted myth that will be explored in greater detail below.

\section{The private sector}

The most prominent feature of the changes in higher education in Brazil in recent years has been the growth of the private sector. While the country has for many years had a high proportion of its students in private institutions, they have until recently been mainly in the 
religious institutions, principally the Catholic Universities known as PUCs ${ }^{6}$. Since the 1990s, however, there has been a rapid growth of smaller profit-making or highly commercialized non-profit institutions aiming to absorb at low cost the large numbers unable to find a place in public universities. While the number of places available in public institutions has risen by $28 \%$ since 1998 , there has been a $133 \%$ increase in the private sector in the same period, with its share of new students now at $76.7 \%$ (INEP 2003b). In the nine months between November 2001 and July 2002 there was a 45\% increase in the number of private institutions; between 1998 and 2001 an average of 2.5 institutions a day were opened (Constantino and Gois 2003).

Six of the seven largest universities in the country are now private: the University of São Paulo, with some 43,000 at graduate level, is now eclipsed by the Universidade Paulista (based in São Paulo) and Estácio de Sá (based in Rio de Janeiro) both with over 85,000 (INEP 2003b). While private involvement is lower than in some countries of Asia (e.g. Philippines and Japan), it is higher than most Latin American countries, and well above the levels of OECD countries. In the USA, the great showcase of private HE, only $23 \%$ of students study in private institutions (NCES 2002).

Many private HEIs in Brazil are part of large business groups, such as the Universidade Paulista, which is linked to a vast chain of primary, secondary and pre-vestibular schools known as Objetivo. The network is developed on a franchise basis and now has a total student population of 485,000 and a yearly turnover of R $\$ 2$ billion (approximately US\$650 million). UniverCidade (sic), a university centre based in Rio de Janeiro, has developed a number of low-cost courses and rapidly expanded its student base to 27,000 in 17 campuses. The head of the institution, Ronald Levinsohn, is infamous for having bankrupted the finance company Delfim in mysterious circumstances in 1982. The growth of university centres such as UniverCidade is resented by the private universities (particularly the Universidade Paulista), who see them as having an unfair advantage in not being required to invest in research and qualified teaching staff. Their costs are claimed to be about $40 \%$ lower, yet they have almost as much autonomy. These university centres, and the 'chain' universities such as Estácio de Sá, rely heavily on branding, with the institutional logo promoted in all available media and large amounts spent on advertising. Campuses are small and well distributed in convenient locations around the city: some are located in shopping centres and even theme parks ${ }^{7}$. 
The latest entry into the market, and perhaps most significant for the future, is Pitágoras. A well established chain of schools, it struck a deal with US education company Apollo in 2001, to develop its first HEI in Belo Horizonte. It has as yet only 1,300 students in two campuses but is set for rapid growth. Pitágoras's curriculum, created principally by Claudio de Moura Castro, ex-Chief Education Advisor to the Inter-American Development Bank, and largely modelled on Apollo's Phoenix University, encapsulates well the ethos of the new universities. The courses are heavily standardized, conceived by a central planning team, and defined and controlled down to the smallest details. This standardization is intended to expand the availability of quality instruction while keeping costs low, and to avoid the necessity of high-level teaching staff (Rosenburg 2002).

The private sector in Brazilian higher education has grown for a number of reasons. Firstly, there has been a vast increase in demand, due to population growth, increasing enrolment at the secondary level and the need for HE diplomas in the job market. Some of this demand has been met by the public sector, but growth has been slow on account of lack of investment. Secondly, entrepreneurs have begun to seen HE as an attractive area of investment: the company Ideal Invest has been set up specifically to advise businesses on entry into the education market. The company estimates that the turnover of private HE should rise from US\$4 billion to US\$10 billion in the next seven years. Thirdly, the government has provided a number of incentives, including tax breaks and cheap loans for developing infrastructure, under the influence of the World Bank policy recommendations outlined above.

The World Bank's three basic justifications for promoting private HE - equity, quality and low public cost - will now be analyzed in the context of Brazil.

\section{Equity}

The policies of the World Bank for higher education are designed to promote economic development with equity. The Bank's report on HE in Brazil states:

Equity can mean different things, for example: i) a reasonable degree of equality of opportunity to participate in higher education, and ii) a reasonable 
and fair balance between paying the costs and obtaining the benefits from higher education. (World Bank 2001: 41)

Firstly it should be noted that in 'i)' the phrase 'reasonable degree' indicates that the Bank considers full equality of opportunity to be either impossible or undesirable. Definition 'ii)' calls for fairness in the relation between private costs and private benefits in education. Fairness according to this second principle means that those willing and able to pay expensive fees (the rich) are entitled to high benefits, while those unable (the poor) are entitled to little or none. This statement clearly fits uneasily with the first, leading to inequality of opportunity in all societies except those with high levels of income equality (not the case of Brazil).

A less problematic definition of equity ${ }^{8}$ in education is that of Brighouse (2002), namely that those "with similar levels of ability and willingness to exert effort should face similar educational prospects regardless of their social background, ethnicity or sex' (Brighouse 2002: 10). The present analysis will focus on this minimal idea of equity, (Brighouse in fact adds a second principle that educational justice must also address the levels of resources directed at people of different abilities, an issue that exceeds the limits of this study).

The first question, therefore, is whether the growth of the private sector is increasing equity in terms of access to higher education. Equity of access requires that all people have a fair chance of attaining one of the existing university places, regardless of their initial place in the social system. However, theoretically there may be a system with a highly just and nondiscriminatory entry system, but nevertheless only offering places to $5 \%$ of the population. It is also necessary, therefore, that there are sufficient places. Equally, a system may have capacity for all, but will not be equitable if certain social groups are confined to lower quality institutions. We can draw two principles:

1. Individuals must have a fair opportunity of obtaining a place in the university of their choice.

2. There must be sufficient places so that all members of society who so desire can participate in higher education. 
The first principle does not require universities to employ no selection criteria at all: only that they do not discriminate against certain candidates on account of their initial place in the social system. There are, clearly, a number of other aspects of equity in HE relating to the experience of students during their studies, but the present analysis will be restricted to the issue of initial access.

At first sight, the private sector in Brazil seems to have contributed to equity by bringing about a rapid increase in the number of university places. It is unlikely that the public sector could have expanded at the rate the private sector has, even if state funding had not been cut. The existence of private universities, with their less competitive entry exams, flexible hours

and, in some cases, location in areas outside the metropolitan centres, have meant that many Brazilians have obtained a university diploma who would not have been able to otherwise. Private universities are, therefore, fulfilling a role in Brazilian society, and there is clearly a strong demand for them from 'consumers'. Nevertheless, it will be argued that the growth of this sector is not in fact contributing to equity in the education system, particularly in the long run.

The first factor is the difficulty of paying fees. Costs for courses vary considerably, from the cheapest at around R $\$ 150$ (there are approximately 3 Brazilian reals to one US dollar) to over $\mathrm{R} \$ 2000$ a month ${ }^{9}$, depending on the institution, geographical location and subject. Table 1 shows the fees of a selection of HE courses in Rio de Janeiro State.

Table 1

Selected monthly course fees (R\$) in Rio de Janeiro State

\begin{tabular}{|l|l|l|l|l|l|l|}
\hline & Administration & Engineering & Medicine & Pedagogy & Mathematics & Nursing \\
\hline PUC-Rio & 769 & 962 & - & 730 & 913 & - \\
\hline UGF & 347 & 610 & 1,167 & 199 & 199 & 469 \\
\hline USS & 367 & - & 1,000 & 247 & 247 & 402 \\
\hline UNIFOA & - & 375 & 1,242 & - & - & 364 \\
\hline
\end{tabular}

Note: PUC-Rio = Pontifícia Universidade Católica, Rio de Janeiro; UGF = Universidade Gama Filho; USS $=$ Universidade Severino Sombra; UNIFOA = Centro Universitário de Volta Redonda.

[Source: Guia Vocacional 2003] 
Figures from the Brazilian Institute of Geography and Statistics (IBGE) from 1997 show that $55.42 \%$ of Brazilians aged between 18 and 24 were living in a household with income below $\mathrm{R} \$ 600$ a month. Working on the calculation made by Hoper Consultancy (2002) that a Brazilian family can spend up to $25 \%$ of its income on fees, almost none of this group - over half of the age cohort - would have been able to afford even the cheapest course. Only $11.81 \%$ had an income of over $\mathrm{R} \$ 1,800$, the amount necessary to pay the fees of the majority of courses.

More recent figures from 2001 show that of $30.6 \%$ of employed Brazilians were earning the minimum wage (R\$180 a month) or less and only $28.6 \%$ were earning over R \$540 (IBGE 2001). Even allowing for small gains in income since this date (large gains are almost impossible given the low GNP growth rate), it is clear that the majority of Brazilians are unable to pay for private HE, even with the recent introduction of low-cost courses.

Another aspect of private HE that works against promoting equity is the relation of course fees to future earning potential after graduation. Courses for high earning professions such as medicine, dentistry and engineering are more expensive than others, such as humanities, pedagogy and social work. There are some exceptions here: law and business studies are relatively cheap courses with potentially high earnings (Bori \& Durham 2000).

Perhaps more significant than the difference between courses is that between institutions. A degree from the PUC has considerably more weight than one from the newer institutions such as UniverCidade, and the fees are correspondingly higher. As can be seen in table 1, studying mathematics at the Universidade Gama Filho in Rio de Janeiro costs R $\$ 199$ a month, compared to R\$913 at the PUC in the same city; in São Paulo, business administration at Unimarília costs $\mathrm{R} \$ 276$, and at IBMEC as much as $\mathrm{R} \$ 1180$. The emergence of low-cost courses in the last five years is a deliberate strategy by education companies to open the HE market up to the lower-middle class, and at first sight seems a positive means of widening access. However, it will ultimately serve to reproduce inequalities by confining students of poorer families to courses and institutions providing diplomas with less value in the employment market.

There are also regional issues. Private institutions are concentrated principally in the SouthEast, the richest region, and the most attractive from a commercial point of view. This 
concentration serves to exacerbate regional disparities: the impoverished North and NorthEast have far lower enrolments and are in greater need of expansion (INEP 2003b).

Access to private HEIs is facilitated by the government student finance (FIES) scheme. This provides a loan of up to $70 \%$ of the course fees, with low (or at least low by Brazilian standards) rates of interest, and repayment spread over a number of years after the completion of the course. Access, however, is restricted by the need for a fiador (a guarantor for the loan) and is normally limited to $60 \%$ of family income. This restriction, however justified from a bank's point of view, is clearly working against the original intention. Demand is high for the approximately 70,000 loans per semester, given that there are nearly a million new places a year in private HEIs.

In addition to the FIES, private universities have their own scholarships. Non-profit institutions are supposed to allocate $20 \%$ of their turnover towards scholarships for disadvantaged groups: in practice, however, this rarely occurs, and those that are given do not always go to those students most in need (Davies 2002). Subsidized places, therefore, provide only a fraction of the total number in private universities. Even with availability of loans, students from poor families may be deterred or face subsequent difficulties, as shown by Ahier (2000) in the case of the UK. The Bank itself observes:

Loans at commercial rates may be a deterrent to poor students, as there are wellknown risks which bear more heavily on those without significant family wealth.

(World Bank 2001: 44)

Is it possible for the private sector to resolve this source of inequity? A possible solution might be fee controls, but this is not supported by the World Bank, due to the negative effect on profit incentives. The Bank envisages the problem of access being solved by an increase in the present low levels of student aid, with a combination of loans (with low or zero public cost) and grants for the most needy. However, given the large percentage of the population that would require assistance, the public expenditure would be such that the arguments in favour of private HE based on their low public burden would no longer be valid. If this burden was absorbed by the private institutions themselves, it would reduce their profitability and therefore their incentive for expansion. In addition to this, increasing the number of assisted places may increase the number of students from low-income families, but it would 
not solve the questions of quality and public good that will be discussed in the following sections.

It seems clear that equity is not compatible with the exclusion resulting from inability to pay fees. The World Declaration on Higher Education (hereafter, the Declaration), resulting from UNESCO's World Conference on Higher Education in 1998, which was supported and heavily influenced by the World Bank, states:

No discrimination can be accepted, no one can be excluded from higher education or its study fields, degree levels and types of institutions on grounds of race, gender, language, religion, or age or because of any economic or social distinctions or physical disabilities. (UNESCO 1998: 16, my emphasis)

The Brazilian system is clearly suffering from this form of discrimination. Evidence shows that the situation is actually worsening, with the proportion of students in HE from the lower income brackets decreasing and those from the higher brackets increasing during the 1990s (Panizzi 2003). The situation is by no means confined to Brazil: $40 \%$ of Colombian students currently drop out due to inability to pay fees (Jerez 2003). As stated above, equity requires both that there are sufficient places and that people have a fair chance of attending the institution of their choice: while the private sector is bringing an expansion in enrolment it is doing so in a highly inequitable way.

\section{Quality}

The second question is that of the quality of the HEIs that have arisen as a result of the growth of the private sector. While in Brazil private institutions are generally considered better at the primary and secondary levels, there is general concern about the quality of the private sector in HE, with the exception of the traditional religious universities.

While there have been attempts to create universal models of quality management in $\mathrm{HE}$ (Srikanthan and Dalrymple 2002), it is highly improbable, and perhaps undesirable, that there should be full consensus on what constitutes a good university, and consequently, on how the institutions should be evaluated. Nevertheless, there are certain factors that can be broadly 
agreed as indicators of quality. These include experienced and well-qualified staff, low student to teacher ratio, ample library and ICT resources, good physical and administrative infrastructure, intellectual autonomy and an environment of research and enquiry. Most would agree that higher education should provide students with both specific, practical life and work skills, and a broader intellectual and academic development.

The Declaration states:

Quality in higher education is a multidimensional concept, which should embrace all its functions, and activities: teaching and academic programmes, research and scholarship, staffing, students, buildings, facilities, equipment, services to the community and the academic environment. (UNESCO 1998: 11)

The principal measure of quality in Brazilian HE is the national assessment popularly known as the provão ${ }^{10}$, introduced in 1995 . This exam is taken once a year by undergraduates throughout the country, with the principle aim not to assess the performance of the individual students, but that of the courses and institutions to which they belong. Private institutions are judged to be considerably worse than public ones in this measure, as can be seen in table 2 , relating to courses in business administration in the year 2000 .

Table 2

Provão scores in business administration in public and private institutions (2000)

\begin{tabular}{|l|l|l|l|l|l|}
\hline & A & B & C & D & E \\
\hline Federal & $43.9 \%$ & $19.5 \%$ & $19.5 \%$ & $7.3 \%$ & $9.8 \%$ \\
\hline State & $31 \%$ & $16.7 \%$ & $33.3 \%$ & $11.9 \%$ & $7.1 \%$ \\
\hline Municipal & $4 \%$ & $32 \%$ & $20 \%$ & $32 \%$ & $12 \%$ \\
\hline $\begin{array}{l}\text { Non-profit } \\
\text { private }\end{array}$ & $6.7 \%$ & $23.9 \%$ & $52.5 \%$ & $10.4 \%$ & $6.7 \%$ \\
\hline $\begin{array}{l}\text { For-profit } \\
\text { private }\end{array}$ & $6.7 \%$ & $12.5 \%$ & $41.3 \%$ & $24.5 \%$ & $14.9 \%$ \\
\hline
\end{tabular}

Note: $\mathrm{A}$ is the highest and $\mathrm{E}$ is the lowest grade.

[Source: Schwartzman, J. and Schwartzman, S. 2002: 23] 
While a number of municipal institutions achieved low grades, the general performance of the public institutions is greatly superior to that of the private ones. Within the private sector, non-profit institutions performed better than for-profit ones. While this table shows only one academic area, it is broadly representative of the distribution of marks. Bori \& Durham (2000: 43) cite the impressive fact that students of public universities from the lower socioeconomic bracket (from families earning less than ten times the minimum wage) performed better on the provão than private university students from the highest bracket (over twenty times the minimum wage).

There are, however, serious problems with the provão as a measure of quality. There is no correction for differences in student intake: the assessment is measuring not the value-added of the institution but the academic level of the students, which is strongly influenced by their previous schooling. Public universities almost always receive the highest performing candidates from secondary school, and it is therefore not surprising that they have better results in the provão.

Nevertheless, even if we discount this highly contentious assessment (currently in the process of being restructured), there are other indicators showing differences between private and public institutions. Firstly, only $12 \%$ of lecturers in private institutions have a $\mathrm{PhD}$, compared to $38.2 \%$ in public institutions (INEP 2003b). In addition, $80 \%$ of those working in the private sector are part-time, and therefore unable to provide the benefits for students and the institution resulting from exclusive dedication. Classes are larger in private institutions, with an average of 16.9 students per teacher compared to 12.5 in public institutions (INEP 2003b). The presence of research programmes and graduate studies in public universities, in addition to being an inherently important part of a HEI's activity, is likely to have a positive effect on the quality of the educational experience for undergraduates. Another indication of quality is the completion rate. While all Brazilian institutions have lower rates than are desirable, private institutions are particularly poor, with an average of only $32 \%$, compared to $50.3 \%$ in federal and $47.7 \%$ in state institutions ${ }^{11}$ (Schwartzman, J. and Schwartzman, S. 2002).

In terms of facilities and infrastructure, the differences are less clear, as many public universities have seen their libraries, laboratories and ICT facilities badly affected by cuts in funding. Many private universities invest heavily in this area, although this varies greatly between institutions. In some cases this is a conscious choice on the part of the private 
institutions, many of which, like Pitágoras, place a higher value on course materials and technology than on teaching and research staff (Rosenburg 2002).

While it is hard to measure this quality in a concrete way, few would argue that the new private HEIs (with a handful of exceptions) are providing an education that is of as high a quality as that provided by the existing public universities. However, it might be argued that this is because the institutions in question are new, and that it takes time to establish a quality university. It is certainly the case that the relatively low level of qualification of academic staff in the private sector is largely due to the lack of academics with post-graduate qualifications nationwide, and that a rapid expansion of the public sector would have encountered the same problem.

Are there, therefore, any factors inherent in the private sector that might cause it to be of lower quality? One possible factor stems from the requirements of cost efficiency. While the need to keep costs low in the interests of profitability may mean that private institutions do not suffer from the heavily bureaucratic inefficiency of the public sector, it does raises worries as regards quality. If the lack of students with sufficient economic power means that fees cannot be raised, then once a high level of efficiency has been achieved, profitability can only be ensured by spending less on facilities, staff and so forth.

Many aspects of quality are linked to resources, meaning that the issue cannot be separated from that of fees and access. While there are important elements of quality - such as ethos or intellectual autonomy - that do not necessarily have a financial cost, university education of higher quality will normally cost more, even if it has a high level of efficiency. Costs can be kept down by distance education, but this is not possible for certain courses, and there is far from consensus that it is an equally effective form of education in any area. In a free-market system, this means that raising quality will mean raising fees, thus excluding a portion of the population and reducing equity.

The incentive for private institutions to raise quality is principally their competition with other institutions - a factor emphasized as a positive feature by the World Bank. There is no doubt that this can bring about genuine increases in quality, particularly those aspects of quality valued by the prospective students. However, this is not the case in situations where there is little competition, or only superficial competition (i.e. where students are restricted to 
one choice due to geographic, economic or other factors). In addition, low quality HEIs may be able to persuade prospective students of the merits of their institution through skilled marketing. Advertising is fundamental to their survival: in 2002, private institutions in the South and South-East spent an average of R $\$ 1,394$ (approximately US\$450) on advertising for each new student enrolled (Hoper 2002). These are costs resulting from competition between rival companies - money which could otherwise be spent on improvements in quality.

Another factor is the diploma itself. Much of the demand for $\mathrm{HE}$ is dependent on the necessity of a university degree for obtaining employment. An institution that can deliver diplomas that will be accepted in the employment market will thrive even if the actual quality of instruction is low.

The World Bank is not oblivious of these dangers. It argues that the State should act as regulator, licensing only those institutions that fulfil certain standards. For this end, Brazil established the National Council of Education (CNE), in 1995 to regulate the opening of new institutions and courses. This evaluation is based firstly on material resources, such as installations, books and computers, and secondly on the intended teaching staff and pedagogical framework (Schwartzman, J. and Schwartzman, S. 2002). However, there is little regulation of courses once they have been accredited, and in cases where irregularities in institutions are discovered, sanctions are rarely imposed. There have been widespread reports of corruption in the granting of licenses, and a number of members of the board have had links to the institutions making applications. Moura Castro- normally a vociferous supporter of the private sector - states:

These requirements, in turn, create an industry which rents libraries and laboratories to institutions aiming for accreditation. Needless to say, as soon as the inspectors' visit is over, the libraries and laboratories are placed in boxes and sent to another institution. (Castro and Navarro 2002: 84) ${ }^{12}$

The difficulties in regulating the private sector, given the power of some of the players, are clearly shown in the case of the CNE. Low-income countries with state apparatuses more fragile than that of Brazil will have even greater difficulty in regulating universities, especially when faced with the entry of powerful foreign companies ${ }^{13}$. 
It has been seen, therefore, that while some of the aspects of low quality in private institutions can be explained as 'teething problems' and difficulties occurring in any context of rapid expansion, there are some factors inherent in a market system.

\section{Public cost and public benefit}

The third argument put forward by the World Bank and others supporting private HE provision is that it brings public benefit at little public cost. The State is seen to lack the funds to provide these services, and private sector input to be essential.

Public universities have considerably higher costs per student than private ones: expenditure per student in federal universities is over three times GDP per capita, compared to 0.86 in all higher education (World Bank 2001 - the latter figure is an estimate by the authors of the Bank's report). This has been used as a justification for preference of private over public provision, showing the greater efficiency of the former. However, the figures are clearly misleading. Most of the difference is due to expenditure on staff: public universities have a lower student to staff ratio and higher salaries than their private counterparts, enabling them to secure high quality full-time staff. In addition, this comparison ignores the disproportionate costs in public universities of research and community outreach, high expenditure on pensions (which non-profit private institutions are not obliged to provide from their own funds) and other features such as university hospitals. Public universities also run more of the expensive courses such as health sciences and engineering, while in private universities cheap courses like business studies are more common. Judgements on efficiency are, therefore, hard to make on straight comparisons of expenditure per student.

While private HE institutions in Brazil are not funded by the government, they do receive a number of benefits and incentives from public funds. The development of the sector in Brazil was not the result of spontaneous entrepreneurial activity, but a deliberate government policy, particularly in the Cardoso administration (Amaral and Polidori 1999, Trindade 2003). Benefits are particularly forthcoming for non-profit institutions. Of all the private HE institutions in Brazil approximately half are profit-making ${ }^{14}$ and half are non-profit, defined either as religious, philanthropic or community-based. However, many commentators 
(including Moura Castro himself) refer to ways in which companies can draw a profit indirectly from their philanthropic educational ventures. Large sums are often siphoned off to associated foundations, vast salaries paid to directors, and benefits accrued from capital gain on the rapid expansion of the HE empires (Davies 2002).

The diversion of public funds to the private sector takes a number of forms. Firstly, for nonprofit institutions there are exemptions from tax and from social security payments for employees. The latter represents an enormous saving, leaving the State responsible for pensions and other employee benefits. Non-profits also enjoy exemption from the so-called education-salary, a social contribution of $2.5 \%$ that businesses make on their salary payments. The State also forfeits up to $\mathrm{R} \$ 500$ million a year in income tax exemption for those paying private university fees (Davies 2002).

Secondly, there is the student loan system, discussed above. In theory, this money is recouped by the State, but it does so with interest rates below market levels, and in many cases the loans are not repaid. Between its creation in $1999^{15}$ and 2003, the FIES enabled the transferral of R \$1.7 billion to private institutions (MEC 2003).

Thirdly, there are grants and low interest loans. Infrastructure development and other activities such as research and community outreach can receive public funding. Grants and subsidies made available to institutions have suffered from the corruption and clientilism that has affected all the regulation of the private

HE sector. Private HEIs also enjoy a wide variety of opportunities of obtaining loans at below market rates. While there are no exact figures, it is estimated that the total amount of public money transferred to private HEIs has reached billions of reals (Davies 2002). This is not in itself a cause for concern if it can be shown that in addition to the direct return they give to their fee-paying beneficiaries these institutions are having a significant public benefit.

The Declaration outlines a number of essential activities of HEIs, relating to responsibilities towards students and towards society in general, one of which is to 'advance, create and disseminate knowledge through research' (UNESCO 1998: 4). Lack of involvement in this area is a well known feature of private HEIs in Brazil. An increasing number of private institutions are university centres and therefore are not obliged to carry out any research. Of those that are universities only the PUCs have significant research programmes. A similar 
picture can be seen in terms of graduate studies: while only $30 \%$ of undergraduates study in public institutions, this figure rises to $82 \%$ at the Master's and $91 \%$ at doctoral levels (IIESALC 2002).

The comments of João Uchôa Cavalcanti Netto, head of the Estácio de Sá chain, that research is 'pompous uselessness' (Folha Dirigida 2001) are not untypical of the attitudes of many private HEIs. Even though other directors of private institutions would value its importance in general terms, they would not see it as essential to an HE institution. That research which is carried out is usually commercially motivated. The research undertaken by the Universidade Paulista, for example, has strong links to the business interests of its owner João Carlos di Genio, in the areas of cattle breeding (he is said to own the most expensive cow in the world), and in establishing patents on Amazonian plants. As much as $8 \%$ of the annual receipts of the group go on research into high-technology didactic materials, bringing benefits to di Genio's large media empire (Parajara 2003).

The linking of research to commercial interests is not confined to private universities, and is today common in all research institutions. However, the danger of the expansion of the private sector is that without a substantial proportion of public funding, money cannot be directed to areas that are not immediately profitable, but may have a long-term economic benefit, or a social or cultural benefit that may not necessarily contribute to economic growth.

It might be argued that research is a luxury that the new 'mass' HE institutions cannot afford and which in any event is superfluous to the principal task of training the workforce. The greatest urgency, it is true, is for expanding enrolment for undergraduates. Nevertheless there are strong arguments for not allowing research to be confined to a few centres of excellence in Brazil, or indeed to be imported from abroad. Firstly, a programme of research and graduate studies is beneficial to students, even those who are not directly involved, as it provides an environment of intellectual vitality. Secondly, the concentration of research in the wealthy countries means that LMICs like Brazil will become increasingly dependent both economically and culturally. Lack of research confines LMICs to a position of providers of primary products and simple industrial goods, while the core industrialized countries maintain power through scientific patents and cultural hegemony. 
There are also issues concerning the types of courses offered. In the private sector these are determined by student demand, cost-efficiency, and for new institutions, limitations of infrastructure (such as difficulties in the purchase of expensive laboratory equipment). There are some significant differences with the courses offered in public universities. Law, business studies and social sciences account over half the enrolment of private institutions, compared to only $26.5 \%$ in the public sector (Schwartzman, J. and Schwartzman, S. 2002). Key areas in which Brazil has a lack of graduates, such as science and technology, have lower rates of enrolment in private institutions, as do important areas of public service such as social work.

HEIs, in addition to tuition and research, have an important role in society as centres of information, documentation, culture, and of critical and independent thought. These functions are less developed in the new private institutions where activities are largely limited to course tuition, where the curriculum is strongly centralized with little teacher input, where there is little investment in research and where that research which is undertaken is strongly linked to commercial interests. In addition, private universities perform less of the function of extensão, the community outreach contribution obligatory in institutions of 'university' classification.

Once again the question must be asked whether these are teething problems or factors inherent in private institutions. There is no reason why private universities should not invest generously in research: one need look no further than the example of Harvard or Stanford, or on a smaller scale the old Catholic universities in Brazil. These, however, are philanthropic institutions with a strong academic commitment and tradition, very different from the new generation of HEIs. The latter, which do not enjoy the secure financial base of endowments and grants of the old philanthropic institutions, depend heavily on fees and must think always in terms of earnings and costs - not in order to increase their academic excellence, but simply to keep afloat in a competitive market. In these circumstances, research that does not have a short-term commercial benefit is unlikely to be undertaken. Many of the theoretical contradictions between educational values and the market model outlined by McMurtry (1991) seem to be borne out in the case of Brazilian HE.

By its very nature a private HEI responds to the demands of the individuals and organizations that fund it, and not those of society as a whole, unless the institution in question is wealthy enough to have relative independence of its sources of funding: perhaps true of Harvard, but 
certainly not of private institutions in LMICs. With their significant public cost, and the limitations in the public benefit provided, it seems difficult to assert that the new private HEIs in Brazil are fulfilling the World Bank's claim of providing a similar service to the public universities at a fraction of the cost.

\section{Conclusion}

The more that better-off families pay for education (as they do when they choose private education), the more the government can use its resources for the poor. (World Bank 1999a: 19)

This 'common sense' statement is strongly persuasive in promoting policies of privatization, but can be seen to be highly problematic. Firstly, the statement says nothing about quality: when public education is only for the poor, or any politically marginalized group, it is likely to be of a lower quality. Secondly, there is inequity among those paying fees, as quality varies between different private institutions and is usually linked to cost. State intervention in the private sector can mitigate some of the inequitable effects of the market, but countries like Brazil with their weaker state apparatuses have less power to regulate fees, provide grants and ensure quality. Even the most developed countries have difficulty in compensating for the poor's disadvantage in a highly privatized system.

The development and financing of higher education in general is not easy to achieve: universities are extremely expensive, and LMICs need to work especially hard to maintain them. The encouragement of the private sector appears an attractive way to bring rapid growth in enrolment at little cost. However, the case of Brazil has shown a number of dangers in this approach: here the World Bank's education policies are clearly not fulfilling their own stated goals of equity and quality. While it is unquestionable that the public universities in Brazil were, and continue to be, highly elitist, it is unclear why efforts are not being made to increase public investment in these institutions, thus expanding and democratizing access.

The private sector is not entirely malevolent, nor is the public sector entirely benevolent. State control can limit intellectual autonomy, and governments are often unwilling or unable 
to expand access to HE. The crucial point is that an equitable expansion, while difficult in the public sector, is impossible in the private sector. An expansion is occurring and can continue, but it is not equitable, firstly because the poorest in society cannot afford unaided the high costs of HE and secondly because those who do have access receive differing levels of quality of education, in proportion to the amount they can spend on fees.

\section{Notes}


${ }^{1}$ There is a third form of privatization, involving private administration of publicly funded institutions, as in the case of companies running state schools in the UK and USA. This, however, has not been such a prominent development in HE.

${ }^{2}$ Both countries have subsequently returned.

${ }^{3}$ Although discrimination on the basis of gender is evident in the Brazilian education system, it does not appear significant in terms of access to university, female students comprising 57\% of the total (INEP 2003b).

${ }^{4}$ Groups of private institutions in the same state sometimes run a single vestibular between them. The National Exam of Secondary Schools is also accepted as an entrance assessment by some private institutions.

${ }^{5}$ The new free-of-charge 'popular' pre-vestibulares, many run by the Black Movement, are a welcome development, but as yet have been unable to bring a significant change in the situation.

${ }^{6}$ Pontifícia Universidade Católica.

${ }^{7}$ An Estácio de Sá campus is found in the Terra Encantada park in Rio de Janeiro.

${ }^{8}$ This paper will not attempt to draw a rigorous distinction between equity and equality: the former is used in the sense of equality of opportunity.

${ }^{9}$ Fees for medicine at Uninove and Unicastelo are $\mathrm{R} \$ 2,200$.

${ }^{10}$ Literally, 'big test'.

${ }^{11}$ These figures may overestimate the actual level of dropout as some students included in the statistics are likely to have transferred to other courses (World Bank 2001: 9).

${ }^{12}$ Author's translation from the original Spanish.

${ }^{13}$ Since Portuguese is the medium of instruction in Brazilian HE, the country is less vulnerable to overseas education investors than, for example, countries in South-East Asia where English is used. Nevertheless, partnerships such as that between Apollo and Pitágoras could enable increasing amounts of foreign investment and influence.

${ }^{14}$ The constitution of 1988 for the first time allowed profit-making in education, on the conditions of following the national educational norms, and authorization and evaluation of quality by the State. (Neves 2002: 138)

${ }^{15}$ The FIES replaced a previously existing scheme known as Creduc.

\section{References}

Ahier, J. (2000) Financing higher education by loans and fees: theorizing and researching the private effects of a public policy, Journal of Education Policy, 15 (6), 683-700.

Altbach, P. (2002) Perspectivas comparadas sobre la educación superior privada, in P. Altbach (ed.) Educación Superior Privada (Mexico City: UNAM).

Amaral, A. and Polidori, M. (1999) Quality evaluation in Brazil: a competency based approach? Higher Education Policy 12 (2), 177-199.

Bori, C. M. and Durham, E. R. (eds.) (2000) Eqüidade e Heterogeneidade no Ensino Superior Brasileiro (Brasília: INEP).

Brighouse, H. (2002) Egalitarian Liberalism and Justice in Education (London: Institute of Education).

Castro, C. de M. and Navarro, J. C. (2002) ¿Puede la mano invisible del mercado reparar la educación superior privada? In P. Altbach (ed.) Educación Superior Privada (Mexico City: UNAM).

Constantino, L. and Gois, A. (2003) Número de faculdades privadas cresce $45 \%$ no país, Folha de São Paulo, 3 August.

Davies, N. (2002) Mecanismos de financiamento: a privatização dos recursos públicos, in L. M. W. Neves (ed.) O Empresariamento da Educação (São Paulo: Xamã). 
Folha Dirigida (2001) A maior das riquezas. Available online at http://www.folhadirigida.com.br/professor2001/cadernos/maior_riqueza/5.html

Gandin, L. and Apple, M. W. (2002) Challenging neo-liberalism, building democracy: creating the citizen school in Porto Alegre, Brazil, Journal of Education Policy 17 (2), 259-279.

Gentili, P. (2001) A universidade na penumbra: o círculo vicioso da precariedade e a privatização do espaço público, in P. Gentili (ed.) Universidades na Penumbra (São Paulo: Cortez).

Gentili, P. and McCowan, T. (eds.) (2003) Reinventar a Escola Pública: Política Educacional para um Novo Brasil. (Petrópolis: Editora Vozes).

Guia Vocacional (2003) Qual a mensalidade? Available online at http://www.guiavocacional.com.br

Hoper (2002) Estratégias de combate a inadimplência. Available online at http://www.hoper.com.br/palestras.htm

IBGE - Instituto Brasileiro de Geografia e Estatísticas (2001) Pesquisa nacional por amostra de domicílios. Available online at

http://www.ibge.gov.br/home/estatistica/populacao/trabalhoerendimento/default.shtm

IIESALC - Instituto Internacional para a Educação Superior na América Latina e no Caribe (2002) $A$ Educação Superior no Brasil (Porto Alegre: IIESALC).

INEP - Instituto Nacional de Estudos e Pesquisas Educacionais (2003a) Edudatabrasil. Available online at http://www.edudatabrasil.inep.gov.br/

INEP - Instituto Nacional de Estudos e Pesquisas Educacionais (2003b) Censo da educação superior 2002. Available online at http://www.inep.gov.br/download/censo/2002/sinopse/Sinopse_2002_censosuperior.zip

Jerez, A. J. (2003) Muchos jóvenes tienen que trabajar en lo que sea para pagar la universidad, El Tiempo, 19 June.

Leher, R. (1999) O BIRD e as reformas neoliberais na educação, PUCVIVA 5, 16-22.

Levy, D. C. (1986) Higher Education and the State in Latin America: Private Challenges to Public Dominance (Chicago: University of Chicago Press).

McCowan, T. (2003) Participation and education in the Landless People's Movement of Brazil, Journal for Critical Education Policy Studies 1(1). Available online at http://www.jceps.com/index.php? pageID $=$ article $\&$ articleID $=6$

McMurtry, J. (1991) Education and the market model, Journal of Philosophy of Education 25(2), 209-219.

MEC - Ministério da Educação (2003) Financiamento estudantil.. Available online at http://www.mec.gov.br/Sesu/fies/

NCES - National Center for Education Statistics (2002) Digest of education statistics. Available online at http://nces.ed.gov//pubs2003/digest02/index.asp

Neves, L. M. W. (2002) Legislação e planejamento no processo de privatização da educação superior, in L. M. W. Neves (ed.) O Empresariamento da Educação (São Paulo: Xamã).

Panizzi, W. P. (2003) Public universities: a benchmark for higher education in Brazil, Higher Education Management and Policy 15 (1), 43-55. 
Parajara, F. (2003) A equação di Genio, Istoé Dinheiro, 14 May.

Rodríguez-Gómez, R. and Alcántara, A. (2001) Multilateral agencies and higher education reform in Latin America, Journal of Education Policy, 16 (6), 507-526.

Rosenburg, C. (2002) O sonho do diploma, Exame, 12 August.

Salomon, M. (2003) Gratuidade nas federais ainda provoca debate, Folha de São Paulo, 3 August.

Schwartzman, J. and Schwartzman, S. (2002) O ensino superior privado como setor econômico. Report commissioned by the National Social Development Bank of Brazil (BNDES).

Srikanthan, G. and Dalrymple, J. F. (2002) Developing a holistic model for quality in higher education, Quality in Higher Education 8(3), 215-225.

The Task Force on Higher Education and Society (2000) Higher Education in Developing Countries: Peril and Promise (Washington, DC: World Bank).

Torres, C. A. \& Schugurensky, D. (2002) The political economy of higher education in the era of neoliberal globalization: Latin America in comparative perspective, Higher Education 43 (4), 429-445.

Trindade, H. (2003) O discurso da crise e a reforma universitária necessária da universidade brasileira, in M. Mollis (ed.) Las Universidades en América Latina: ¿Reformadas o Alteradas? (Buenos Aires: CLACSO).

World Bank (1994) Higher Education: the Lessons of Experience (Washington, DC: World Bank).

World Bank (1999a) Education Sector Strategy (Washington, DC: World Bank Human Development Group).

World Bank (1999b) Educational Change in Latin America and the Caribbean (Washington, DC: World Bank).

World Bank (2001) Higher Education in Brazil: Challenges and Options (Washington, DC: World Bank Human Development Group).

UNESCO (1998) World Declaration on Higher Education for the Twenty-First Century: Vision and Action, adopted at the World Conference on Higher Education, Paris, October 1998.

UNESCO (2001) Statistical tables: education. Available online at http://portal.unesco.org/uis/ev.php?

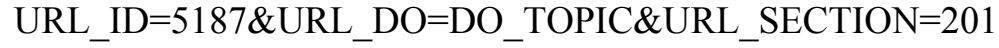

